\title{
Atypical voltinism in mulberry silkworm Bombyx mori L., 1758 (Lepidoptera: Bombycidae) races Barapat and Barapolu
}

\author{
Kiran Rudramuni= ${ }^{\circledR}{ }^{\circledR}$, Shiv Kumar ${ }^{\circledR}$, Bharath K. Neelaboina ${ }^{\circledR}$, Mir N. Ahmad ${ }^{\circledR}$, \\ Sukhen R. Chowdhury
}

Silkworm Division, Central Sericultural Research and Training Institute, Central Silk Board, J\&K, India.

拝=CCorresponding author: kiranrmv1990@gmail.com

\author{
Edited by: Elio C. Guzzo
}

Received: August 10, 2020. Accepted: November 06, 2020. Published: January 04, 2021.

\begin{abstract}
The mulberry silkworm, Bombyx mori L., 1758 (Lepidoptera: Bombycidae) is classified as univoltine, bivoltine, and polyvoltine based on the annual brood frequency. Voltinism in B. mori is characterized by the occurrence of embryonic diapause (facultative and obligatory diapause). Univoltine silkworms suited to cold and temperate regions lay diapausing eggs and polyvoltine silkworms suited to tropical regions lay nondiapausing eggs. In contrast, the occurrence of diapause in bivoltine silkworms is influenced by the environment. In addition to the difference in the occurrence of embryonic diapause, larval duration, and cocoon characters show distinct variations. In the present correspondence, we are presenting an interesting observation from two silkworm races Barapath and Barapolu originating from the North-East region of India that display divergence in voltinism. The unique characteristic features of univoltine, bivoltine, and polyvoltine observed in the races are discussed explaining the occurrence.
\end{abstract}

Keywords: Diapause, non-diapause, temperate, univoltine.

The silkworm, Bombyx mori L., 1758 (Lepidoptera: Bombycidae), originating from its wild ancestor, Bombyx mandarina Moore, 1852 (Lepidoptera: Bombycidae) is the only invertebrate species entirely domesticated due to its economic importance. The process of domestication of this unique insect species represents Darwin's theory of artificial selection where the species evolved rapidly due to the strong artificial selection under human intervention to produce desired traits (Xiang et al. 2018; Zhu et al. 2019). This domesticated lepidopteran exhibits wide diverse morpho-biochemical and biometric characters and has been the subject of much interest due to its variation in voltinism (Awasthi et al. 2008).

A significant disparity exists among these holometabolous insects regarding the number of generations produced per year, which varies from univoltine to bivoltine or to polyvoltine for the virtue of producing one, two, or multiple broods annually and thus is an important criterion for the scientific classification. Voltinism is determined in diapause or non-diapause eggs where the univoltine eggs enter diapause every generation (obligatory diapause), the bivoltine eggs diapause expression is determined by environmental cues (facultative diapause) and the polyvoltine eggs never enter diapause (Yamashita \& Yaginuma 1991; Nurakami \& Yoshiki 1989; Muniraju \& Mundkur 2018). In addition to the difference in the occurrence of embryonic diapause, larval duration, and cocoon characters show distinct variations. The dominance in larval duration and cocoon characters among three voltines are recognised in the order of univoltine $>$ bivoltine $>$ polyvoltine (Otsuki \& Sato 1997; Muniraju \& Mundkur 2018).

The embryonic diapause in $B$. mori is trans-generationally induced under maternal control where embryonic diapause is an alternative developmental program in the life cycle accomplished by developmental, behavioral and physiological events (Yamashita 1996; Sato et al. 2014). Diapause occurs in the late gastrula stage of embryogenesis during which embryonic cell cycle gets arrested in $G_{2}$ phase exclusive of a small fraction of continuously cycling cells (Nakagaki et al. 1991). Eggs in dormancy are identified as seasonal polyphenism characterized by lower metabolic activity, a halt in dermal differentiation and changes in the chorion permeability responsible for the oxygen-deficient environment (Saheb et al. 1990; Sasibhushan et al. 2012).

The voltinism in silkworm is not consistent as a whole. For instance, Barapat and Barapolu races preserved in Central Sericultural Research and Training Institute, Pampore under germplasm breeding programme as genetic resources under temperate conditions have shown atypical voltinism. A considerable discrepancy exists in the literature with reference to voltinism of these two races. According to Ghosh \& Ghosh (1995), Chandra \& Choudhury (2001) and Singh (2004), Barapat and Barapolu originate from North-East region of India and belong to the race Textor, are univoltine in nature and spins greenishwhite or pure white cocoons. On the contrary, Chauhan \& Tayal (2007) and Kumaresan et al. (2004) identified Barapolu as a polyvoltine race. As per Muniraju \& Mundkur (2018), Barapolu is an exotic univoltine race and was tropicalized in West Bengal. Considering the discrepancy, the present correspondence aims to provide details of the results of the rearing under temperate conditions.

Under temperate conditions, silkworm races Barapat and Barapolu were reared during spring (May) under standard rearing conditions (Krishnaswami 1978; 1983). The young age larvae $\left(1^{\text {st }}\right.$ to $3^{\text {rd }}$ instars) were reared on leaves of mulberry varieties KNG and Ichinose (27$\left.28{ }^{\circ} \mathrm{C}: 85-90 \% \mathrm{RH}\right)$ and the late age larvae ( $4^{\text {th }}$ and $5^{\text {th }}$ instars) on Goshoerami leaves $\left(24-26{ }^{\circ} \mathrm{C}: 70-80 \% \mathrm{RH}\right)$. Both races were reared in three replications, and about 250 larvae were retained after the third moult for further studies. The mature larvae at the end of $5^{\text {th }}$ instar were collected manually and transferred to collapsible plastic mountages for cocooning. The eggs laid by the emerging moths were incubated at $25^{\circ} \mathrm{C}$ to maintain a diapause state. Larvae and cocoons from the rearing period were assessed using the following equations.

Larval weight $(\mathrm{g})$ : Weight of 10 randomly selected 5 -day old $5^{\text {th }}$ instar larvae $(\mathrm{g}) / 10$

Cocoon weight (g): Weight of 10 cocoons $(\mathrm{g}) / 10$

Shell weight (g): Weight of 10 cocoon shells $(\mathrm{g}) / 10$

Shell ratio (\%): Single cocoon shell weight (g)/ Single cocoon weight (g) $\times 100$

Silk filament length $(\mathrm{m})$ : Revolutions of aprovette (No.) $\times$ 
circumference of wheel (m).

Temperate region of Kashmir is considered conducive for the rearing of univoltine races due to the availability of nutritive mulberry leaves that sprout in spring after hibernation during severe winter (Narayanan \& Tikoo 1969). Interestingly under temperate conditions, these races are identified by atypical voltinism. Few moths from 2019 spring rearing laid non-diapause eggs mixed with diapause eggs (Tab. 1). ANOVA analysis conducted between non-diapause and diapause eggs showed that the number of non-diapause eggs was significantly lower than diapause eggs (Barapat: $F=844.019$; $d f=1,18 ; p<0.0001$; Barapolu: $F=624.441 ; d f=1,18 ; p<0.0001)$. According to McCracken (1909), the occurrence of bivoltine in univoltine is a rare event described by the author as a reversion to an ancestral condition.

Table 1. Non-diapause and diapause eggs laid by Barapat and Barapolu silkworm races.

\begin{tabular}{cccccc}
\hline Race & $\begin{array}{c}\text { No. of } \\
\text { DFL* }\end{array}$ & $\begin{array}{c}\text { Eggs } \\
\text { (Mean } \pm \text { SE) }\end{array}$ & $\begin{array}{c}\text { Non-diapause } \\
\text { eggs (Mean } \pm \text { SE) }\end{array}$ & $\begin{array}{c}\text { Diapause } \\
\text { eggs } \\
\text { (Mean } \pm S E)\end{array}$ & $\begin{array}{c}\text { Hatchability } \\
\text { (\%) } \\
\text { (Mean } \pm S E)\end{array}$ \\
\hline Barapat & 10 & $357.6 \pm 12.43$ & $7.3 \pm 3.11$ & $299.2 \pm 9.55$ & $85.82 \pm 1.38$ \\
Barapolu & 10 & $328.7 \pm 12.90$ & $8.6 \pm 4.43$ & $275.7 \pm 9.73$ & $86.63 \pm 1.64$ \\
\hline
\end{tabular}

*Disease Free Layings

A bivoltine silkworm exhibits a maternally controlled diapause determined by the environmental cues such as photoperiod, temperature, humidity, and nutrition received by mother while in the embryo stage. Among the abiotic factors, temperature and photoperiod play a significant role in diapause of bivoltine silkworm, particularly during the later incubation period of embryonic development. Incubation temperature of $15{ }^{\circ} \mathrm{C}$ under continuous darkness and $25{ }^{\circ} \mathrm{C}$ under continuous illumination result in non-diapause and diapause eggs, respectively (Watanabe 1919), whereas a transient temperature and photoperiod could lead to the occurrence of both diapause and non-diapause eggs. According to the study by Sato et al. (2014), temperature above $21^{\circ} \mathrm{C}$ activates the temperature-sensitive ion channel BmTrpA1 during which the induction of diapause in the progeny is affected. The study also reported that BmTrpA1 knockdown induces non-diapause eggs in progeny. In contrast, multivoltine moths in tropical conditions lay non-diapausing eggs at $25{ }^{\circ} \mathrm{C}$ and embryos continue to grow without entering diapause (Otsuki \& Sato 1997; Sato 2014).

Univoltine eggs are characterized by unique colouration pattern during the oviposition, i.e., yellow or light-yellow coloured eggs are destined to spin white cocoons, and deeper yellow or golden coloured eggs are destined to spin yellow cocoons (McCracken 1909; Mukherjee 1912). Though there is a shift in the voltinism of these races, the colouration patterns of eggs, freshly hatched larvae and cocoons are still observed (Fig. 1).

In comparison to univoltine and bivoltine silkworm, larval size of polyvoltine is small, and larval duration is shorter (Otsuki \& Sato 1997). The average larval duration of a bivoltine silkworm reared under germplasm programme ranges between 25 and 26 days. In the case of Barapat and Barapolu, the larva is small in size and average duration of the larval period was $26.00 \pm 0.07$ and $25.10 \pm 0.04$ days, repectively. In terms of average weight, the two races weighed $26.34 \pm 1.08$ and
$25.33 \pm 1.09$, respectively, lowest among the other races maintained under germplasm programme.

The cocoon characters of polyvoltine, bivoltine, and univoltine silkworm show distinct variability. The cocoon characters cocoon weight, cocoon shell weight, shell ratio, and cocoon filament length of univoltine and bivoltine are high when compared to a polyvoltine silkworm (Babu 2013). The average filament length of cocoon ranges between 300-400 $\mathrm{m}$ for polyvoltine and between 800-1200 m for bivoltine and univoltine races. The average cocoon weight $(\mathrm{g})$, shell weight (\%), shell ratio (g) and filament length $(\mathrm{m})$ of Barapat and Barapolu were $1.14 \pm 0.01,0.12 \pm 0.01,10.53 \pm 0.56$ and $584 \pm 6.75$ and $0.96 \pm 0.01,0.11 \pm 0.01,10.94 \pm 0.29$ and $513 \pm 15.60$, respectively, lowest among other races maintained.

In the molecular evaluation study conducted by Awasthi et al. (2008), Barapolu showed a great genetic distance from bivoltine and polyvoltine races. Among the genotype group studied, Barapolu, originating from North-East India showed a closer genetic relationship with bivoltine race Feng shong, originating from China, indicating origin from similar geographical regions.

In general, univoltine and bivoltine breeds from China, Japan, and Korea are ecologically adapted to temperate conditions where diapause serves as a mechanism to cope with both severe winter climatic conditions and to host availability. In comparison, tropical polyvoltine populations lack the ability to diapause due to the availability of favourable conditions (Nurakami \& Yosshiki 1989; Awasthi et al. 2008; Haghighi \& Kumar 2017). Mulberry sericulture in India thrives under diverse climatic conditions ranging from temperate to tropical. Hence, these races are performing according to the ecological conditions cuing that induction or acquisition of diapause phenomenon seems to be adaptive.

Similarly, this view is supported by the study where a tropical nondiapausing polyvoltine race from Indonesia was introduced in Japan, and the life cycle of the race changed according to the seasonality. Most of the eggs laid in spring were non-diapausing and a mixture of diapause and non-diapausing eggs were laid in summer followed by diapausing eggs almost in autumn. The transformation was evidenced by two recessive genes, $n p n d$ and pnd for controlling the non-diapause state and $n p n d^{+}$and $p n d^{+}$for the diapause state (Katsumata 1968; Yamamoto et al. 1978; Murakami 1989; Nurakami \& Yoshiki 1989). According to Yamamoto et al. (1978), the npnd gene confers high adaptability to a wide range of change in climatic conditions, whereas pnd is indifferent to the climatic conditions. These observations indicate that mulberry silkworms with genetic endowment facilitate the adaptive ability to different environmental conditions.

Since sericultural regions of India are composed of diverse weather patterns, it becomes essential for the silkworm to attain physiological and genetic diversification especially due to its evolution under the influence of diverse agro-climatic factors, limited cultural exchange between countries participating in sericulture and human intervention at every step in the process of domestication.
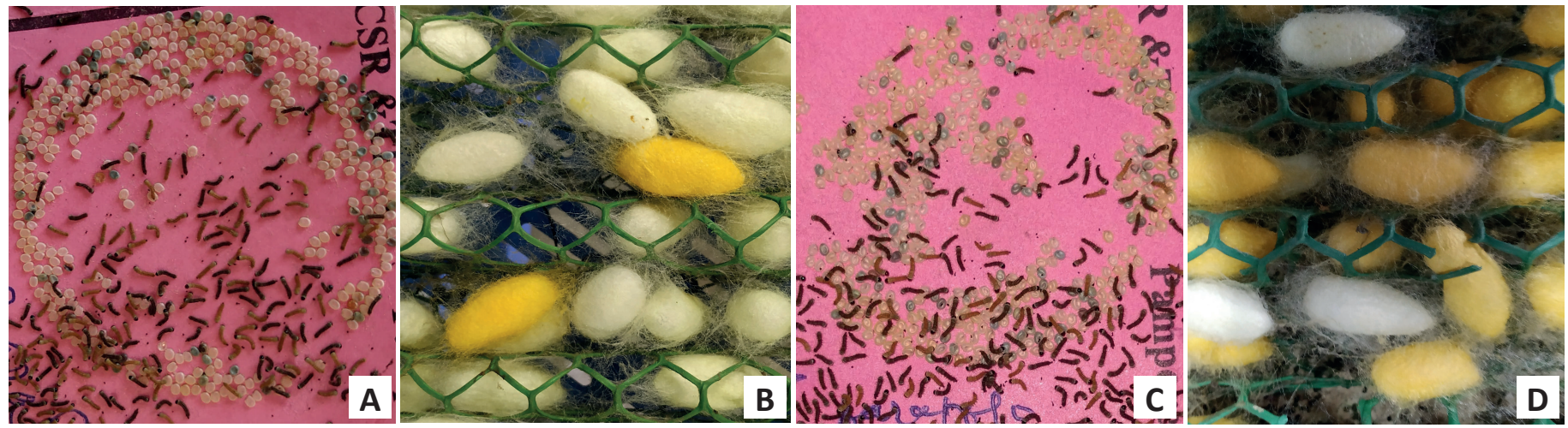

Figure 1. Unique coloration patterns in freshly hatched larva and cocoons of silkworm races Barapath (A, B) and Barapolu (C, D). 


\section{Acknowledgements}

The authors would like to thank Central Silk Board and Central Sericultural Research and Training Institute, Pampore, Jammu and Kashmir for providing financial assistance.

\section{Authors' Contributions}

KR, SK, BKN performed the data collection. KR reviewed the literature and wrote the manuscript. SK, BKN, MNA, and SRC contributed to the revision of the manuscript. All the authors approved the final version of the manuscript.

\section{References}

Awasthi, A. K.; Kar, P. K.; Srivastava, P. P.; Rawat, N.; Vijayan, K. Pradeep, A. R.; Raje, U.S. (2008) Molecular evaluation of bivoltine, polyvoltine and mutant silkworm (Bombyx mori L.) with RAPD, ISSR and RFLP-STS markers. Indian Journal of Biotechnology, 7: 188-194.

Babu, M. K. (2013) Introduction to silk and sericulture, In: Babu M. K. (Ed.), Silk, pp 1-32. Cambridge: Woodhead Publishing.

Chandra, G. S.; Choudhury, T. K. R. (2001) Sericulture in India: Industrial application from seventeenth to nineteenth century, Journal of Scientific and Industrial Research, 60(5): 369-377.

Chauhan, T. P. S.; Tayal, M. K. (2007) Mulberry Sericulture. In: Omkar (Ed.) Industrial Entomology, pp 197 -263. Singapore: Springer.

Ghosh, G. K.; Ghosh, S. (1995) Indian textiles: past and present, pp 6061. New Delhi: APH Publishing.

Haghighi, M. T.; Kumar, J. T. S. (2017) Genetic divergence and allelicspecificity in relation to expression of voltinism in silkworm using ISSR and RAPD fingerprinting, Russian Journal of Genetics, 53: 267274. doi: $10.1134 / S 102279541702003 X$

Katsumata, F. (1968) Non maternal inheritance in Voltinism observed in the crossing experiments between Indonesian polyvoltine and Japanese bivoltine races of silkworm, Bombyx mori. The Journal of Sericultural Science of Japan, 37: 453-461.

Krishnaswami, S. (1978) New technology of silkworm rearing. Mysore: Central Sericultural Research and Training Institute. Bulletin No. 2.

Krishnaswami, S. (1983) Evolution of new bivoltine races for traditionally multivoltine areas of south India. Indian Silk, 22: 3-11.

Kumaresan, P.; Sinha, R. K.; Mohan, B.; Thangavelu, K. (2004) Conservation of Multivoltine Silkworm (Bombyx mori L.) Germplasm in India-An Overview. International Journal of Industrial Entomology, 9(1): 1-13.

McCracken, I. (1909) Heredity of the race-characters univoltinism and bivoltinism in the silkworm (Bombyx mori). A case of nonMendelian inheritance. Journal of Experimental Zoology, 7(4): 747764.

Mukherjee, N. G. (1912) Handbook of sericulture. Calcutta: Bengal Secretariat Book Depot.

Muniraju, E.; Mundkur, R. (2018) Tracing of Evolution in Silkworm, Bombyx mori L., on the Basis of Molecular Studies. In: Kumar, D.; Gong, C. (Eds.), Trends in Insect Molecular Biology and Biotechnology, pp 67-84. Calcutta: Springer.

Murakami, A. (1989) Genetic Studies on Tropical Races of Silkworm (Bombyx mori) with Special Reference to Cross Breeding Strategy between Tropical and Temperate Races 2. Multivoltine silkworm strains in Japan and their origin. Japan Agricultural Research Quarterly, 23(2): 127-133.

Nakagaki, M.; Takei, R.; Nagashima, E.; Yaginuma, T. (1991) Cell cycles in embryos of the silkworm, Bombyx mori: G2- arrest at diapause stage. Roux Archives of Developmental Biology, 200(4): 223-229.

Narayanan, E. S.; Tikoo, B. L. (1969) Evolution of new races of univoltine silkworm by physiological genetics, Proceedings of Indian Academy of Sciences Section B, 69: 320-335.

Nurakami, A.; Yoshiki, O. (1989) Genetic Studies on Tropical Races of Silkworm (Bombyx mori) with Special Reference to Cross Breeding Strategy between Tropical and Temperate Races 1. Genetic nature of the tropical multivoltine strain Cambodge. Japan Agriculture
Research Quarterly, 23(1): 37- 45.

Otsuki, R.; Sato, S. (1997) Silkworm Egg Production (Translated from Japanese). New Delhi: Oxford and IBH Publishing Co. Pvt. Ltd.

Saheb, B.; Sengupta, N. M. K.; Reddy, V. G. (1990) Treatise on the acid treatment of silkworm eggs. Mysore: Central Sericultural Research and Training Institute.

Sasibhushan, S.; Kangayam, M.; Ponnuvel; Nanjappa, B.; Vijayaprakash. (2012) Diapause specific gene expression in the eggs of multivoltine silkworm Bombyx mori, identified by suppressive subtractive hybridization. Comparative Biochemistry and Physiology - Part B, 161(4): 371-379.

Sato, A.; Sokabe, T.; Kashio, M.; Yasukochi, Y.; Tominaga, M.; Shiomi, K. (2014) Embryonic thermosensitive TRPA1 determines transgenerational diapause phenotype of the silkworm, Bombyx mori. Proceedings of National Academy of Sciences, 111(13): E1249-E1255.

Singh, T. (2004) Principles and techniques of silkworm seed production. New Delhi: Discovery Publishing House.

Watanabe, K. (1919) Studies on the voltinism in the silkworm Bombix mori. Bulletin of Sericultural Experiment Station, 3.

Xiang, H.; Liu, X.; Li, M.; Zhu, Y. N.; Wang, L.; Cui, Y.; Liu, L.; Fang, G.,; Qian, H.; Xu, A.; Wang, W. (2018) The evolutionary road from wild moth to domestic silkworm. Nature Ecology \& Evolution, 2(8): 1268-1279. doi: 10.1038/s41559-018-0593-4

Yamamoto, T.; Gamo, T.; Hirobe, T. (1978) Genetical studies of the pigmented and non-diapausing egg mutant in Bombyx mori. The Journal of Sericultural Science of Japan, 47: 181-185.

Yamashita, O. (1996) Diapause hormone of the silkworm, Bombyx mori: structure, gene expression and function. Journal of Insect Physiology, 42(7): 669-679.

Yamashita, O.; Yaginuma, T. (1991) Silkworm eggs at low temperatures: Implication for sericulture. In: Lee, J. R. E.; Denlinger, D. L. (Eds.) Insects at Low Temperature, pp 424-445. New York: Chapman and Hall.

Zhu; Ya-Nan; Li-Zhi, W.; Cen-Cen, Li.; Yong, C.; Man, W; Yong-Jian, L.; Ruo-Ping, Z,; Wen, W.; Hui, X. (2019) Artificial selection on storage protein 1 possibly contributes to increase of hatchability during silkworm domestication. PLoS Genetics, 15(1): e1007616. doi: 10.1371/journal.pgen.1007616 